January 2019

\title{
Inciting, Requesting, Provoking, or Persuading Others to Commit Crimes: The Legacy of Schenck and Abrams in Free Speech Jurisprudence
}

Larry Alexander

University of San Diego

\section{Recommended Citation}

Larry Alexander, Inciting, Requesting, Provoking, or Persuading Others to Commit Crimes: The Legacy of Schenck and Abrams in Free Speech Jurisprudence, 72 SMU L. REV. 389 (2019)

https://scholar.smu.edu/smulr/vol72/iss3/4 


\title{
Inciting, Requesting, Provoking, or Persuading Others to Commit Crimes: The Legacy of SCHENCK and Abrams in Free Speech JURISPRUDENCE
}

\author{
Larry Alexander*
}

I

N 1919, in Schenck v. United States ${ }^{1}$ and Abrams v. United States, ${ }^{2}$ the U.S. Supreme Court made its initial foray into establishing the meaning of the First Amendment's free speech clause. Those cases involved prosecutions that were reactions to the Left's opposition to World War I and to the Red Scare following the Russian Revolution of 1917. In both cases, the Court upheld the defendants' convictions of conspiracy to urge others to obstruct the war effort. In Schenck, Holmes wrote the opinion of the Court and announced the so-called "clear and present danger" test. ${ }^{3}$ " "The question in every case is whether the words used are used in such circumstances and are of such a nature as to create a clear and present danger that they will bring about the substantive evils that Congress has a right to prevent.") 4 In Abrams, Holmes dissented, arguing that the test in Schenck was not satisfied. ${ }^{5}$

Both Schenck and Abrams involved regulations of the content of speech where the connection between the speech and the feared harm is a two-step connection. The first step is for the speech to be heard or read by the speaker's audience. The second step is for the audience to cause the harm. Moreover, if the second step occurs, the government can legitimately punish the audience, for the audience is presumably responsible for so acting. ${ }^{6}$

At this point, I am going to digress and contrast this two-step paradigm for regulation of speech based on its content with the one-step paradigm for content regulation, which has been central in most of the modern free speech cases in the Supreme Court. When speech causes harms that the

* Warren Distinguished Professor, University of San Diego School of Law. I want to thank Fred Schauer and Steve Smith for their comments.

1. 249 U.S. 47 (1919).

2. 250 U.S. 616 (1919).

3. Schenck, 249 U.S. at 82.

4. Id.

5. Abrams, 250 U.S. at 627-31 (Holmes, J., dissenting).

6. However, it is not always going to be the case that the audience will be responsible for its harmful acts. See infra p. 391. 
government wishes to prevent, many of those harms occur when the audience hears or reads the speech. Speech that reveals secrets, confidential communications, or private embarrassing facts is an example. So too is speech that offends, causes emotional distress, infringes copyright, or breaches a contract. At other times, however, the harm only occurs when the audience believes the speech-such as when the speech falsely portrays someone unflatteringly-or when the audience acts in response to the speech in ways the government cannot legitimately prevent or lacks the ability to prevent, such as when the audience acts to its detriment in response to false, deceptive, or threatening speech. This incapacity of the government to prevent the harms that come from the audience's believing what the speaker asserts is not only the case with deceptive speech, threats, and defamation. It is also the case with advocacy of crimes when the audience, or part thereof, cannot be held legally responsible for the harms they cause, such as when they are mentally ill or minors.

The Court's jurisprudence of the one-step paradigm of content regulations developed later than its two-step jurisprudence. ${ }^{7}$ So too did its jurisprudence of non-content-based regulation of speech, what-following Laurence Tribe-I call Track Two jurisprudence. ${ }^{8}$ And the Court has never really developed a jurisprudence for government speech. ${ }^{9}$

It is easy to see why the government will want to suppress speech that causes harm in one step. If it cannot silence the speaker, it cannot prevent the one-step harms from occurring. But speech that causes harm in two steps is more problematic. If the government cannot punish the speaker or otherwise prevent the speaker from communicating with the speaker's intended audience, it can still attempt to prevent the harm by threatening the audience with punishment. It is not surprising, therefore, that two of the most important defenses of freedom of speech-by Thomas Scanlon ${ }^{10}$ and David Strauss ${ }^{11}$-focus on the two-step paradigm and base their defense of freedom of speech on the audience's right to hear the speech and decide whether to act as the speaker is advocating or persuading them to act. For if the audience is persuaded to act illegally, the government can still attempt to deter them from doing so by the threat of punishment. The government need not interdict the communication from the speaker to the audience in order to have a chance to prevent the harm; and, per Scanlon and Strauss, when the government does interdict the communication, it exceeds the authority autonomous citizens would grant it ${ }^{12}$ and

7. Perhaps as late as Beauharnais v. Illinois, 343 U.S. 250 (1952).

8. See Larry Alexander, Is There a Right of Freedom of Expression? 13-14, 82 (2005); Laurence H. Tribe, American Constitutional Law 792 (2d ed. 1988).

9. See Alexander, supra note 8, at 87, 91. (1972).

10. Thomas Scanlon, $A$ Theory of Freedom of Expression, 1 Phil. \& Pub. Aff. 204

11. David A. Strauss, Persuasion, Autonomy, and Freedom of Expression, 91 Colum. L. Rev. 334 (1991).

12. Scanlon states as follows:

There are certain harms which, although they would not occur but for certain acts of expression, nonetheless cannot be taken as part of a justification for 
infringes the audience's right to make up its own mind. ${ }^{13}$

The case against content regulations based on the two-step paradigm, most forcefully made by Scanlon and Strauss, is not without its problems. First, as mentioned above, some in the speaker's audience may not be, as Scanlon and Strauss imagine, fully autonomous. ${ }^{14}$ They may be minors or insane. In such cases, the two-step paradigm is really a one-step paradigm, and the government can only threaten punishment of the speaker as its means for preventing the harm.

Second, even if the government can punish the audience if it causes harms, the government may not know who or where the relevant audience is. Or the audience, unlike the speaker, may be undeterred by the threat of punishment.

Third, if some of the audience were persuaded by the speaker to act illegally, would this not reveal that their reasoning was defective? If so, why should the government respect their ability to decide whether to heed the speaker? (Consider that when we sanction speakers for defamations or deceptions, we do so for fear that the audience will believe what it should not believe. But we do not think we are disrespecting the audience's ability to decide for itself. And would Scanlon and Strauss object to the many laws that deprive law-abiding persons of items, such as some guns or explosives, on the ground that some persons will use them illegally? The parallel with the laws against advocacy of crimes is obvious. $)^{15}$ In short, why should the audience's interest in being able to decide whether to break the law be an interest that freedom of speech protects? ${ }^{16}$

Finally, why should we hold the audience responsible for being persuaded to act as advocated but not for being persuaded by defamatory or deceptive speech? The two common justifications offered for this distinction are unpersuasive. One is that advocacy involves opinions, but defamation and deception involve false assertions of facts. The other is that advocacy involves values, not false assertions of facts. But opinions can only persuade if the audience believes they rest on factual bases. If the speaker revealed all the facts on which his opinion is based, including the speaker's method of reasoning, the addition of "in my opinion, these facts prove ..." would not add any ounce of persuasiveness to the revealed facts. ${ }^{17}$ Similarly, assertions of value, if they are to be persuasive, must be more than just bare emotings, which are no more persuasive than burps.

legal restrictions on these acts ... merely [because] . . . the act of expression led the agents [who would cause the harm] to believe (or increased their tendency to believe) these acts to be worth performing.

Scanlon, supra note 10, at 213.

13. "[H] armful consequences resulting from . . . persuasive effects of speech may not be any part of the justification for restricting speech." Strauss, supra note 11, at 335.

14. Scanlon, supra note 10, at 215; Strauss, supra note 11, at 353-54.

15. See, e.g., Frederick Schauer, On the Distinction Between Speech and Action, 65 EMORY L.J. 427, 444-49 (2015).

16. I thank Fred Schauer for this pithy summation of the paragraph. See id. at 447.

17. See Alexander, supra note 8, at 70-71. 
They must contain implicit factual assertions. As I said in my book on freedom of expression:

A statement asserting an incorrect value must at some level be mistaken factually or imply a fact that does not exist (such as that the speaker has some special moral insight). When all the relevant facts about the world and the speaker are disclosed to the audience, the speaker's assertions of value will themselves be inert . . . ${ }^{18}$

So the distinction between advocacy and false statements of fact, in terms of what the audience should be deemed responsible for acting on, is an untenable distinction.

The two-step paradigm that was present in Schenck and Abrams was present in almost all of the early free speech cases before the Court. In 1951, however, in Dennis v. United States, which involved advocacy of the overthrow of the government by the Communist Party, the Court appeared to abandon the clear and present danger test in favor of Judge Learned Hand's cost-benefit test. ${ }^{19}$ ("In each case [courts] must ask whether the gravity of the 'evil,' discounted by its improbability, justifies such invasion of free speech as is necessary to avoid the danger." ${ }^{20}$ (Query: How should the courts assign a value to the cost side of the equation, the suppression of the message? Will the loss of the message be evaluated based on the courts' sympathy or lack thereof with the message? How can it not be?)

Finally, in 1969, the Court's free speech jurisprudence for dealing with the two-step paradigm took another turn. In Brandenburg v. Ohio, a case involving a speech at a Ku Klux Klan rally, the Court, in reversing Brandenburg's conviction for advocacy of violence, stated that the guarantee of free speech does not permit the government to proscribe advocacy of the use of force or law violation "except where such advocacy is directed to inciting or producing imminent lawless action and is likely to incite or produce such action." 21

In the fifty years since Brandenburg was decided, the Court has never given any indication that it might have second thoughts about the test for the two-step paradigm that it announced in Brandenburg. ${ }^{22}$ The Brandenburg test is thus the current descendant of the Schenck and Abrams clear and present danger test. So it is worth taking a close look at that test.

18. Id. at 71

19. Dennis v. United States, 341 U.S. 494, 510 (1951).

20. Id.

21. Brandenburg v. Ohio, 395 U.S. 444, 447 (1969) (per curiam).

22. It is possible, however, that the Court's decision in Holder v. Humanitarian Law Project, 561 U.S. 1, 39 (2010), represents a retreat from the intent requirement of Brandenburg, although it is equally possible that Holder is a sui generis carve-out for speech that assists terrorist organizations. I discuss the intent requirement in the paragraphs that follow. And I note that "fighting words," which like advocacy also cause harm in two steps, can apparently be punished without proof that the speaker intended the audience to attack him. See Chaplinsky v. New Hampshire, 315 U.S. 568, 572-73 (1942); see also Cantwell v. Connecticut, 310 U.S. 296, 309 (1940) (denying the necessity of an intent to provoke violence); Feiner v. New York, 340 U.S. 315, 320-21 (1951) (to the same effect). 
According to Brandenburg, punishable advocacy must be directed to producing the harm. ${ }^{23}$ Almost everyone reads this to be a requirement that the speaker intends to produce the harm (through the acts of his audience). And that is a natural reading of the Court's use of the term "directed." 24

If the Court is requiring intent, does that make sense? Intent is a type of mens rea in criminal law, and so it might be germane in a criminal prosecution of the speaker. But the interests of criminal law and the interests of freedom of speech are not the same. In the latter realm, we want to know when the government can interdict speech because of its content in order to prevent downstream harms. If the speaker's speech is going to cause the audience to decide to commit crimes, why should we care whether the speaker intended the audience to do so, knew the audience would, was reckless with respect to whether the audience would, was negligent with respect to whether the audience would, or was completely nonculpable with respect to whether the audience would? (In the latter case, imagine the government does not threaten punishment but just unplugs the microphone of the nonculpable advocate.) Or consider a case where the government has possession of some pamphlets that appear to advocate crimes and that are to be delivered to thousands of addressees, but the government does not know who the author is much less what his intent is. Must it ascertain that intent before it determines whether to deliver or destroy the pamphlets? The speaker who intends the downstream harms may be more culpable than the speaker who does not; but insofar as the government's concern is with preventing the downstream harms, the culpability of the speaker does not affect its reasons for interdicting the speech. ${ }^{25}$

Consider next Brandenburg's requirement that the advocated lawless action must be "imminent." 26 This is typically defended on the ground that if there is time to counter the problematic speech with speech, that should be the route the government takes.

But why should imminence matter except insofar as it affects the likelihood of the harm, which likelihood is another element of the Brandenburg test? After all, even if the speech is indefinite about when the harm it advocates will occur, or even if the harm advocated is to occur in a year or two years or beyond, and if, despite and notwithstanding the possibility of counterspeech, the harm remains above the required threshold of likelihood, why should the government be required to refrain from interdicting the speech? Whatever measures, other than interdicting the speech,

23. Brandenburg, 395 U.S. at 447.

24. It is not the only possible meaning of the term, however. It could just refer to the conventional meaning of the speaker's words, a suggestion I owe to Fred Schauer. I do think that referent of "directed" is quite unlikely because it would make it possible to incite intentionally by carefully choosing one's words.

25. See generally AleXANDER, supra note 8, at 76 (providing similar examples that render an intent requirement for punishable two-step harm speech questionable).

26. Brandenburg, 395 U.S. at 447. 
the government might take to prevent the harm from occurring, by hypothesis, these will not reduce the likelihood of the harm sufficiently. ${ }^{27}$

So assume that we eliminate both the requirement of intent and the requirement of imminency from the Brandenburg test-the former because it is immaterial to the government's free speech concern, the latter because it is not independent of the likelihood requirement-that leaves likelihood of harm as the one material element of the Brandenburg test and brings that test pretty close to the clear and present danger test of Brandenburg's forebears.

But how do we gauge likelihood? Suppose the police are monitoring the speech and the audience and can stop the audience from acting before any harm is produced, even though, were they not present, harm would almost certainly have occurred. Would the advocacy meet the likelihood of harm requirement of Brandenburg? Is likelihood to be assessed as if the police were not present, or does their presence bear on likelihood as Brandenburg intends it to be understood?

Or consider a case in which the speaker has misidentified his audience. He is urging them to "take to the streets," thinking they are the local cell of anarchists, when they are in fact the local "fans of Mr. Rogers" club. Should likelihood be assessed by what is likely to result from the speaker's advocacy or by what he believes is likely to result? If the former, then consider garden variety cases of criminal solicitation, in which the solicitor-the advocate-believes he is dealing with a hit man when he solicits the murder of his business rival but is really dealing with an undercover cop, who will immediately slap the cuffs on him. The law has no problem treating this as a crime despite the unlikelihood that the solicited conduct would have occurred. So, in such cases, likelihood, if it is relevant at all, is not assessed based on who the audience is but on who the solicitor believes the audience is. ${ }^{28}$

The crime of solicitation raises the more general question of why the Brandenburg test does not appear to apply to it. For criminal solicitation is just the advocacy of a crime. ${ }^{29}$ And it typically requires an intent that the crime be committed, satisfying the "directed to" component of Brandenburg. But, as stated above, solicitation does not require the likelihood that the crime solicited will be committed. Nor does it require that the commission of the crime solicited be imminent. (Solicitation of a crime that is to be committed a year or longer in the future is still a criminal solicitation; the temporal location of the solicited crime is not an element of the crime of solicitation. $)^{30}$

27. See also AleXANDER, supra note 8, at 76-77.

28. Other preparatory crimes are detected because of police monitoring of the defendants' activities, so that there is little likelihood that they would have eventuated in harm. Yet this does not preclude their being punished.

29. See, e.g., Model Penal Code $§ 5.02$ (Am. Law Inst. 1962) (presenting a typical definition of criminal solicitation).

30. See id. 
Finally, would it not seem sensible, as per the Hand test in Dennis, to make the imminence relevant only as it affects likelihood; to make likelihood relevant only as it discounts the gravity of the harm advocated; and to weigh the discounted harm against the value of the advocacy? Of course, no matter how difficult assessing imminence and likelihood will be, their assessment will be, in theory, value free. The same cannot be said of assessing the value of the advocacy. Courts cannot make that assessment without relying on their own values. There is no value-free way of assessing value.

The takeaway, for me at least, is that despite the First Amendment ideal of content-neutrality, content-neutrality in the realm of the two-step paradigm of speech regulation is either undesirable or impossible. A truly value-free, content-neutral approach would either require that the government never punish the advocate and only punish the audience when and if the audience acts as advocated, or require that the government treat all advocacy of crimes as it now treats garden variety criminal solicitation. ${ }^{31}$ If neither of those value-free approaches is deemed desirable, then the courts will have to make judgments that will not be value-free and content-neutral. ${ }^{32}$

The same is true, by the way, with respect to the one-step paradigm of speech regulation. When freedom of speech is pitted against the values of secrecy, confidentiality, privacy, reputation, intellectual property, and freedom from deception, fear, emotional distress, and offense, the only value-free, content-neutral approaches are free speech always prevails or never prevails. ${ }^{33}$ If neither of those approaches is desirable, then the courts will have no choice but to bring their values to bear on fashioning free speech doctrines. And because the courts are organs of the government, the government will not be acting in a content-neutral manner, despite the dogma that it is so required. ${ }^{34}$

The Supreme Court has produced a lot of free speech doctrines in the century since Schenck and Abrams. Those doctrines have been controversial as articulated and controversial as applied. Had those doctrines been different, I suspect the same would have been true of them. The essential meaning of freedom of speech is that the government is not to use its coercive machinery to favor a position held by some citizens over the opposing position held by other citizens. But that kind of content neutrality is either undesirable or unachievable whether one thinks freedom of speech rests upon the value of autonomy, democracy, or distrust of government. We have come a long way from Schenck and Abrams in one sense but, in another, it is not clear we have gotten anywhere.

31. See Alexander, supra note 8 , at 81 .

32. Id.

33. Id. at 66,80 .

34. Id. at 80 . 
